\title{
The growth relationships in maiden trees of sour cherry 'Lutówka'
}

\author{
Janusz Lipecki ${ }^{\dagger}$, Tomasz Lipa, Iwona Szot* \\ Department of Pomology, University of Life Sciences, Leszczyńskiego 58, 20-068 Lublin, Poland
}

\begin{abstract}
The studies were conducted in a nursery of sour cherry 'Lutówka' budded on Prunus mahaleb L. in the years 1993, 2000-2003, and 2013. The height of trees, the diameter of stems, and the length of lateral shoots were measured. The air temperature and precipitation higher than the long-term mean (by approximately $10 \%$ and $28 \%$, respectively) contributed to the increase in the stem diameter, the total length of shoots, and the number of shoots per tree. The length of lateral shoots increased from the top of the crown towards the lower parts, however, the number of feathers per tree and the mean length of shoots decreased. A strong positive relationship $(r=0.74, P<0.05)$ was revealed between the stem diameter and the total length of shoots. Generally, the correlations between the type of growth of sour cherry maiden trees and morphological traits were similar to those characteristic for apple maiden trees or "knip-boom" type trees.
\end{abstract}

Keywords: nursery; lateral shoots; stem diameter; growth parameters

\section{Introduction}

Numerous studies deal with the relationship between the types of growth of maiden trees of various fruit tree species and their morphology [1-6]. Data concerning sour cherries in this respect are limited. Therefore, the aim of the experiments was to reveal the effect of several procedures (such as nutrition, time and height of budding) on the quality of maiden trees [7-11]. Some research has been conducted on sour cherry rootstocks in nurseries [12,13]. Kramer [14] found a strong correlation between the stem diameter and other features of sour cherry maiden trees and low variability in tree height in comparison to the stem diameter. The tree height should be considered as a good indicator for tree quality evaluation [14]. However, experiments conducted on apple maiden trees have proved that the stem diameter is a more adequate reflection of tree quality than its height $[1,3,4]$. Sour cherry production in Poland is on a gradual increase [15] and therefore, to meet farmers' expectations, high-quality planting material is required.

The present study was undertaken to identify the morphological traits that allow for quick evaluation of tree quality. A more specific goal of the study was to find out relationships between $(i)$ the type of tree growth and the size of lateral shoots, (ii) the size of lateral shoots and their number per tree, and (iii) the morphology of lateral shoots with regard to their position on the stem.

\footnotetext{
${ }^{\dagger}$ This author died during editorial process.

* Corresponding author. Email: szoti@autograf.pl

Handling Editor: Elżbieta Weryszko-Chmielewska
}

\section{Material and methods}

All measurements were performed in a commercial nursery situated in the Lublin region (51.285 N; 22.619 E), Poland. The soil was characterized by medium content of nutrients and no irrigation was applied. For example, in 2013 the content of nutrients in the topsoil layer $(0-20 \mathrm{~cm})$ was: $\mathrm{P}-17.8, \mathrm{~K}-14.9$, and $\mathrm{Mg} 10.0 \mathrm{mg} / 100 \mathrm{~g}$ of soil, soil $\mathrm{pH}=6.51$. The experiments were conducted in the years 1993, 2000-2003, and 2013. The number of maiden trees measured was $n=198$ in 1993, $n=42$ in 2000, $n=49$ in 2001, $n=30$ in 2002, $n=32$ in 2003, and $n=30$ in 2013, i.e., $n=381$ maiden trees in total. The sour cherry 'Łutówka' was chip-budded on seedlings of Prunus mahaleb L. All lateral shoots below the average height of $49.2 \mathrm{~cm}$ above the ground level were removed during the vegetation period. The exact height values of the level of lateral shoots in the consecutive years were the following: $32.0 ; 50.7 ; 58.3 ; 46.7 ; 54.0$; and 53.4 $\mathrm{cm}$. The tree height, the stem diameter at a height of $30 \mathrm{~cm}$, and the length of lateral shoots were measured each year in the autumn (in November) and then the total length of shoots per tree and the average length of one lateral shoot, depending on its position on the stem and on the number of laterals per tree, were calculated. The measurements were done on every 10-15 trees in randomly selected tree rows, excluding plants that were injured or deformed. The total number of measured trees in the consecutive years is given in Tab. 1. The results concerning the size of trees in the years 2000-2003 were already published [16], so only the data from the year 1993 and 2013 and the averages for the total period of the experiments are included in this paper 
Tab. 1 The difference in the total number of lateral shoots present on experimental trees of the sour cherry 'Łutówka' during the study period.

\begin{tabular}{|c|c|c|c|c|c|c|c|c|}
\hline \multirow{3}{*}{$\begin{array}{l}\text { Number } \\
\text { of } \\
\text { lateral } \\
\text { shoots } \\
\text { per tree }\end{array}$} & \multicolumn{6}{|c|}{ Year of study } & \multirow{3}{*}{\multicolumn{2}{|c|}{$\begin{array}{c}\text { Percentage } \\
\text { of trees } \\
\text { with } \\
\text { different } \\
\text { numbers } \\
\text { of lateral } \\
\text { shoots (\%) }\end{array}$}} \\
\hline & 1993 & 2000 & 2001 & 2002 & 2003 & 2013 & & \\
\hline & \multicolumn{6}{|c|}{ Number of trees } & & \\
\hline 2 & 9 & 3 & & & & & 12 & 3.1 \\
\hline 3 & 23 & 3 & & & & & 26 & 6.8 \\
\hline 4 & 41 & 4 & 1 & & & 1 & 47 & 12.3 \\
\hline 5 & 37 & 5 & & & 1 & 1 & 44 & 11.6 \\
\hline 6 & 42 & 2 & 2 & & 4 & 5 & 55 & 14.4 \\
\hline 7 & 29 & 5 & 6 & & 6 & 6 & 52 & 13.7 \\
\hline 8 & 16 & 8 & 5 & 1 & 8 & 6 & 44 & 11.6 \\
\hline 9 & & 4 & 10 & 5 & 5 & 7 & 31 & 8.1 \\
\hline 10 & 1 & 5 & 13 & 10 & 5 & 3 & 37 & 9.7 \\
\hline 11 & & 2 & 4 & 10 & 2 & 1 & 19 & 5.0 \\
\hline 12 & & & 4 & 3 & & & 7 & 1.8 \\
\hline 13 & & 1 & 2 & & & & 3 & 0.8 \\
\hline 14 & & & 1 & 1 & 1 & & 3 & 0.8 \\
\hline 15 & & & 1 & & & & 1 & 0.3 \\
\hline Total & 198 & 42 & 49 & 30 & 32 & 30 & 381 & 100 \\
\hline
\end{tabular}

(Tab. 2). The experimental trees were grown according to the complete randomized block design.

A parametric statistical analysis (ANOVA) was applied to the analyzed criteria of trees: tree height, length of lateral shoots, stem diameter, total length of shoots, and number of shoots per tree. A post hoc comparison of means was tested using HSD Tukey's test. Pearson's correlation coefficient $(r)$ was applied to measure the strength of the relationship between the chosen morphological tree traits. Pearson's correlation coefficient is an usual measure of linear association which varies from -1 to +1 , with 0 indicating no relationship, +1 indicating a perfect relationship, and -1 a perfect negative relationship. The level of statistical significance for all analyses was at $P=0.05$.

All analyses were performed using STATISTICA for Windows 5.5A software (StatSoft Poland, Krakow).

There was a high variation in weather conditions in the experimental years (Tab. 3). In spring, the average daily air temperatures were higher than the long-term mean (1951-2012), with the exception of March 1993, 2013, April 2003, and May 2002. The air temperature in summer higher than the long-term mean was recorded in 2002 and 2003. The average monthly air temperature during summer time in 1993 was lower than the long-term mean. In July, total precipitation was higher than the long-term mean for 2000, 2001, 2002, 2003 and 2013. On the contrary, August was characterized by a shortage of rainfall and the precipitation was 3-7-fold lower than the long-term mean (expect for the year 2001 when the precipitation was at the average level).

\section{Results}

The lowest number of shoots per one tree was 2 , the highest -15 (Tab. 1). The $63.6 \%$ of maiden trees had 4 to 8 shoots. The best branching was observed in the year 2002, the poorest one in 2000. Similarly, the smallest variation in shoot number was revealed in 2002, with only 6 classes, whereas the biggest one was observed in 2000 and 2001 (11 classes).

An increase by approximately $20 \%$ in maiden tree size was noted in 2013 compared to 1993, however the difference was not statistically significant $(P>0.05)$. It was mainly the effect

Tab. 2 Growth characteristics of maiden trees of sour cherry 'Łutówka' in the year 1993 and 2013.

\begin{tabular}{lllllc}
\hline Years & Tree height $\mathbf{( \mathbf { c m } )}$ & $\begin{array}{l}\text { Stem diameter } \\
(\mathbf{m m})\end{array}$ & $\begin{array}{l}\text { Total length of } \\
\text { shoots } \mathbf{( c m})\end{array}$ & $\begin{array}{l}\text { No. of shoots per } \\
\text { tree }\end{array}$ & $\begin{array}{l}\text { Mean length of } \\
\text { shoot } \mathbf{c m}\end{array}$ \\
\hline 1993 & $143.6 \mathrm{a}^{*}$ & $14.4 \mathrm{a}$ & $410.0 \mathrm{a}$ & $5.40 \mathrm{a}$ & $76.0 \mathrm{a}$ \\
2013 & $164.1 \mathrm{a}$ & $18.7 \mathrm{~b}$ & $524.0 \mathrm{~b}$ & $7.77 \mathrm{~b}$ & $67.4 \mathrm{a}$ \\
\hline
\end{tabular}

* Means followed by different letters differ significantly between years at $P<0.05$, based on HSD Tukey's test. 
Tab. 3 Mean monthly air temperatures and precipitation in the years 1993, 2000-2003, and 2013 relative to the long-term mean values (1951-2012) in the Lublin region (Felin), Poland.

\begin{tabular}{|c|c|c|c|c|c|c|c|c|c|c|c|c|c|c|}
\hline \multirow[b]{3}{*}{ Month } & \multicolumn{7}{|c|}{ Temperature $\left({ }^{\circ} \mathrm{C}\right)$} & \multicolumn{7}{|c|}{ Precipitation totals $(\mathrm{mm})$} \\
\hline & \multicolumn{6}{|c|}{ Monthly mean } & \multirow{2}{*}{$\begin{array}{l}\text { Long- } \\
\text { term } \\
\text { mean }\end{array}$} & \multicolumn{6}{|c|}{ Monthly total } & \multirow{2}{*}{$\begin{array}{c}\text { Long- } \\
\text { term } \\
\text { mean }\end{array}$} \\
\hline & 1993 & 2000 & 2001 & 2002 & 2003 & 2013 & & 1993 & 2000 & 2001 & 2002 & 2003 & 2013 & \\
\hline March & -0.2 & 1.8 & 2.2 & 4.7 & 1.6 & -2.4 & 1.0 & 23.4 & 64.9 & 33.8 & 33.2 & 6.6 & 60.8 & 28.0 \\
\hline April & 8.1 & 11.1 & 8.5 & 8.6 & 6.5 & 8.1 & 7.4 & 15.4 & 69.8 & 64.9 & 18.3 & 40.7 & 51.1 & 39.0 \\
\hline May & 15.9 & 14.5 & 13.9 & 12.4 & 16.3 & 15.3 & 13.0 & 33.9 & 50.7 & 19.9 & 28.6 & 71.4 & 101.6 & 60.7 \\
\hline June & 15.3 & 17.0 & 15.3 & 17.8 & 17.4 & 18.5 & 16.3 & 59.8 & 36.4 & 47.6 & 116.8 & 39.6 & 105.9 & 65.9 \\
\hline July & 16.3 & 17.0 & 21.6 & 21.6 & 19.8 & 19.2 & 18.0 & 73.8 & 138.1 & 260.9 & 126.2 & 98.1 & 126.1 & 82.0 \\
\hline August & 16.5 & 18.2 & 19.7 & 20.5 & 18.9 & 19.2 & 17.2 & 27.0 & 28.3 & 67.5 & 18.7 & 27.0 & 17.8 & 70.7 \\
\hline September & 11.8 & 11.1 & 11.9 & 12.9 & 13.5 & 11.8 & 12.6 & 36.3 & 66.7 & 125.8 & 42.5 & 29.0 & 64.6 & 53.7 \\
\hline $\begin{array}{l}\text { Mean/sum } \\
\text { for year }\end{array}$ & 6.7 & 8.8 & 8.0 & 7.5 & 7.9 & 8.5 & 7.7 & 456.5 & 849.2 & 921.8 & 623.4 & 462.6 & 715.7 & 558.9 \\
\hline
\end{tabular}

of progress in production methods, not being the subject of the study in this paper. The average shoot length was similar in 1993 and in 2013. A significant year effect was found for all the other morphological criteria of maiden tree (Tab. 2).

The length of lateral shoots gradually increased towards the low part of maiden trees (Tab. 4). The regularity of the length of lateral shoots changes; its increase from the top of the tree towards its lower parts was clearly visible. Small deviations were observed in case of the 10th and 11th shoots from the top.
The longest shoots developed on trees with 4 laterals. The length of a single shoot decreased if the number of laterals increased to 12. A weak tendency towards a decrease in shoot length was observed (which means that more feathers per tree $=$ shorter feathers; Tab. 5).

The relationships between the measured criteria of tree morphology (Tab. 6) were positive and significant $(P=0.05)$. The only exception was the correlation between the number of shoots and the mean shoot length. The correlation was negative and significant, both in 2000 and 2003. Strong

Tab. 4 Length of lateral shoots $(\mathrm{cm})$ of sour cherry 'Łutówka' depending on their position on the stem, measured from the top of the crown during the study period.

\begin{tabular}{|c|c|c|c|c|c|c|c|}
\hline \multirow{2}{*}{$\begin{array}{l}\text { Lateral shoot } \\
\text { position from } \\
\text { the top of the } \\
\text { crown }\end{array}$} & \multicolumn{6}{|c|}{ Year of study } & \multirow[b]{2}{*}{ Mean* } \\
\hline & 1993 & 2000 & 2001 & 2002 & 2003 & 2013 & \\
\hline 1 & $64(n=198)$ & $21(n=42)$ & $40(n=49)$ & $44(n=30)$ & $52(n=32)$ & $46(n=30)$ & $44.5 \mathrm{a}$ \\
\hline 2 & $70(n=198)$ & $28(n=42)$ & $42(n=49)$ & $44(n=30)$ & $55(n=32)$ & $56(n=30)$ & $49.2 \mathrm{ab}$ \\
\hline 3 & $71(n=189)$ & $29(n=39)$ & $45(n=49)$ & $50(n=30)$ & $60(n=32)$ & $61(n=30)$ & $52.7 \mathrm{ab}$ \\
\hline 4 & $79(n=166)$ & $32(n=36)$ & $41(n=49)$ & $47(n=30)$ & $65(n=32)$ & $63(n=30)$ & $54.5 \mathrm{ab}$ \\
\hline 5 & $79(n=125)$ & $33(n=32)$ & $48(n=49)$ & $50(n=30)$ & $67(n=32)$ & $74(n=29)$ & $58.5 \mathrm{a}-\mathrm{c}$ \\
\hline 6 & $86(n=88)$ & $36(n=27)$ & $52(n=49)$ & $58(n=30)$ & $68(n=31)$ & $73(n=28)$ & $62.2 \mathrm{a}-\mathrm{c}$ \\
\hline 7 & $89(n=46)$ & $39(n=25)$ & $57(n=46)$ & $58(n=30)$ & $69(n=28)$ & $80(n=23)$ & $65.3 \mathrm{a}-\mathrm{c}$ \\
\hline 8 & $94(n=17)$ & $42(n=20)$ & $62(n=40)$ & $65(n=30)$ & $65(n=22)$ & $87(n=17)$ & $69.2 \mathrm{a}-\mathrm{c}$ \\
\hline 9 & $78(n=1)$ & $43(n=12)$ & $64(n=35)$ & $75(n=29)$ & $76(n=13)$ & $90(n=11)$ & $71.0 \mathrm{a}-\mathrm{c}$ \\
\hline 10 & $29(n=1)$ & $48(n=8)$ & $73(n=25)$ & $83(n=24)$ & $71(n=8)$ & $94(n=4)$ & $66.3 \mathrm{a}-\mathrm{c}$ \\
\hline 11 & & $44(n=3)$ & $73(n=12)$ & $85(n=14)$ & $74(n=3)$ & $52(n=1)$ & $65.6 \mathrm{a}-\mathrm{c}$ \\
\hline 12 & & $65(n=1)$ & $72(n=8)$ & $102(n=4)$ & $72(n=1)$ & & $77.7 \mathrm{bc}$ \\
\hline 13 & & $75(n=1)$ & $72(n=4)$ & $89(n=1)$ & $71(n=1)$ & & $76.7 \mathrm{bc}$ \\
\hline 14 & & & $67(n=2)$ & $82(n=1)$ & $111(n=1)$ & & $86.7 \mathrm{c}$ \\
\hline 15 & & & $87(n=1)$ & & & & $87.0 \mathrm{c}$ \\
\hline Mean** & $73.9 \mathrm{~B}$ & $41.2 \mathrm{~A}$ & 59.7 B & $66.6 \mathrm{~B}$ & $69.7 \mathrm{~B}$ & $70.6 \mathrm{~B}$ & \\
\hline
\end{tabular}

* Means within the column followed by different letters differ significantly between study objects at $P<0.05$, based on HSD Tukey's test. ${ }^{* *}$ Means followed by different letters within the row differ significantly between years at $P<0.05$, based on HSD Tukey's test. 
Tab. 5 Length of lateral shoots of sour cherry 'Łutówka' depending on the number of lateral shoots per tree during the study period.

\begin{tabular}{|c|c|c|c|c|c|c|c|}
\hline \multirow{2}{*}{$\begin{array}{l}\text { Number of } \\
\text { shoots per } \\
\text { tree }(\mathrm{cm})\end{array}$} & \multicolumn{6}{|c|}{ Year of study } & \multirow[b]{2}{*}{ Mean* } \\
\hline & 1993 & 2000 & 2001 & 2002 & 2003 & 2013 & \\
\hline 2 & 71 & 44 & & & & & $57.5 \mathrm{~b}-\mathrm{d}$ \\
\hline 3 & 75 & 39 & & & & & $57.0 \mathrm{~b}-\mathrm{d}$ \\
\hline 4 & 75 & 38 & 67 & & & 79 & $64.7 \mathrm{~d}$ \\
\hline 5 & 75 & 31 & & & 54 & 61 & $55.3 \mathrm{~b}-\mathrm{d}$ \\
\hline 6 & 74 & 32 & 69 & & 72 & 72 & $63.8 \mathrm{~cd}$ \\
\hline 7 & 73 & 37 & 55 & & 67 & 63 & $59.0 \mathrm{~b}-\mathrm{d}$ \\
\hline 8 & 74 & 30 & 48 & 52 & 67 & 66 & $56.2 b-d$ \\
\hline 9 & & 32 & 48 & 54 & 66 & 71 & $54.2 \mathrm{~b}-\mathrm{d}$ \\
\hline 10 & 70 & 29 & 52 & 58 & 63 & 69 & $56.8 \mathrm{~b}-\mathrm{d}$ \\
\hline 11 & & 29 & 62 & 62 & 47 & 69 & $53.8 \mathrm{bc}$ \\
\hline 12 & & & 50 & 58 & & & $54.0 \mathrm{bc}$ \\
\hline 13 & & 43 & 43 & & & & $43.0 \mathrm{a}$ \\
\hline 14 & & & 46 & 59 & 57 & & $54.0 \mathrm{bc}$ \\
\hline 15 & & & 49 & & & & $49.0 \mathrm{ab}$ \\
\hline
\end{tabular}

* Means within the column followed by different letters differ significantly between study objects at $P<0.05$, based on HSD Tukey's test.

correlation was between the total length of lateral shoots and their number $(r=0.74)$, the stem diameter and the total length of lateral shoots $(r=0.65)$, the total shoot length and the mean shoot length $(r=0.52)$. The average value of the coefficient was highest for the sum of the length of lateral shoots $(r=0.60)$, while the lowest one - for the number of shoots per tree $(r=0.31)$. These values were characterized by high regularity in 4 out of 6 years - the exceptions were the year 1993 and 2002.

\section{Discussion}

Quality of planting material is very important for early yielding in intensive orchard systems and for quick economic returns. In orchards with intense management, feathered trees are preferred. The present study proved the influence of air temperature and precipitation higher than the long-term mean on the number of lateral shoots and on the variation in shoot number. Our study did not reveal the year effect on the tree height and mean length of shoots. However, significant differences were found in the stem diameter, total length of shoots, and number of shoots per tree. The obtained results could be related to high precipitation in June and July and high summer temperatures in 2002 (including August), which created good conditions for tree growth. Our results are in agreement with Wociór et al. [17] who observed significant changes in the morphological traits of sour cherry 'Łutówka', depending on the year. In their study, the year effect was more important than the formation methods for the stem diameter, tree height, total length of lateral shoots, number of feathers, and mean length of shoots. Frost which occurred in late April and early May caused damage of the scion bud, which was visible on the section. This resulted in significant retardation of the growth of maiden trees. The effect of environmental conditions on the growth of sour cherry maiden trees was also pointed out by Baryła [18], who indicated that the increase in height of young cherry

Tab. 6 Pearson's correlation coefficients $(r)$ between criteria measured.

\begin{tabular}{lcccc}
\hline Growth parameter & Tree height & Stem diameter & Number of shoots & Total length of shoots \\
\hline Tree height & $\times$ & $0.46^{*}$ & 0.22 & $0.47^{*}$ \\
Stem diameter & $\times$ & $0.38^{*}$ & $0.65^{*}$ & $0.40^{*}$ \\
Number of shoots & & $\times$ & $0.74^{*}$ & $\times .46^{*}$ \\
Total length of shoots & & & -0.12 \\
\hline
\end{tabular}

Coefficients marked with asterisks $\left({ }^{*}\right)$ are significant at $P<0.05$. 
trees on stock types for the May-June and July-August periods depended significantly on the total of mean daily temperatures for the May-June and July-August periods and the average maximum and minimum daily temperatures over the period.

Growth intensity, easiness of crown formation as well as early and high cropping are dependent on the type and quality of trees used for planting. The results concerning the maiden's size obtained in the years 2000-2003 were already published [16] and they were intermediate between those obtained in the years 1993 and 2013. The size of maiden trees determined in this experiment was in most cases bigger than that reported by Baryła and Kapłan $[9,10]$ for the same region. Our results are similar to some recently published results $[9,10]$ and to those obtained by Wociór et al. [17]. The results obtained in 2013 were close to or better than the means for 5 years, probably due to heavy precipitation and high temperatures in spring (May-June) 2013. It should be stressed that in 1993 all lateral shoots from the low part of the stem were removed up to $32 \mathrm{~cm}$ of the tree, whereas this height reached $53 \mathrm{~cm}$ in the other years, which certainly influenced the results.

Our results are in accordance with those obtained for apple maiden trees [1] and apple knip-boom trees [19]. For example, the values of Pearson's coefficients calculated between stem diameter and total length of lateral shoots were as follows: for sour cherries $r=0.65$, for apple maidens $r=0.67$, and for apple knip-boom trees $r=0.70$, all being

\section{Acknowledgments}

The research was supported by the Ministry of Science and Higher Education in Poland as part of the statutory activities of the Pomology Department of the University of Life Sciences in Lublin.

\section{Authors' contributions}

The following declarations about authors' contributions to the research have been made: concept JL; field work JL, TL, IS; data analysis and manuscript development: JL, TL, IS.

\section{Competing interests}

No competing interests have been declared.

\section{References}

1. Lipecki J, Janisz A. Zależności między cechami charakteryzującymi wzrost okulantów jabłoni. Zesz Nauk Akad Rol im H Kołłątaja Krak. 1999;66:67-71.

2. Słowiński A, Sadowski A. Wzrost i rozgałęzianie okulantów jabłoni 'Elise' w szkółce w zależności od podkładki. Zesz Nauk Inst Sadow Kwiac im Szczepana Pieniążka. 2000;67-72.

3. Jacyna T. Studies on natural and chemically induced branching in temperate fruit and ornamental trees [PhD thesis]. Lublin: Wydawnictwo Akademii Rolniczej; 2001. (Rozprawy Naukowe; vol 246).

4. Jacyna T. Growth correlations in apple nursery trees. Ann Univ Mariae Curie-Skłodowska EEE. 2007;17(1):9-16.

5. Milošević , Milošević N. Growth and branching of pear trees (Pyrus domestica, Rosaceae) in nursery. Acta Sci Pol Hortorum Cultus. 2010;9(4):193-205.

6. Stachowiak A, Świerczyński S. Growth of maiden apple trees of 'Galaxy' and 'Rubin' on rootstocks clones originating from crossing A. $2 \times$ B.9. Acta Sci Pol Hortorum Cultus. 2011;10(2):49-59.

7. Baryła P. Effect of planting density on the growth and quality of cherry young trees of cultivar 'Eutówka' on the stock of sweet cherry significant. The discrepancy between our results and those of Kramer [14] could be explained by the differences in environmental conditions between the study sites, the cultivar effects, and rootstock properties (e.g., providing the roots and the stem to support the new plant, obtaining the soil water and minerals, resisting the pests and diseases). Grzyb et al. $[13,20]$ pointed out that the response of sour cherry nursery trees to fertilization is affected by cultivar and rootstock type.

\section{Conclusions}

The mean length of lateral feathers on sour cherry maiden trees increased gradually from the top of the crown towards its lower part.

The mean length of lateral feathers decreased if the number of shoots per tree increased, but this correlation was weak and significant only in some cases.

The strongest relation was found between the stem diameter and the total length of lateral shoots. A negative correlation was revealed between the number of features and their mean length.

Differences in tree growth between years were probably due to the weather conditions. The air temperature and precipitation higher than the long-term mean contributed to the larger stem diameter, caused an increase in the total length of shoots, and impacted the increase in the number of shoots per tree.

tree Prunus avium L. Ann Univ Mariae Curie-Skłodowska EEE. 2005;15:35-42.

8. Baryła P. The effect of the time and methods of budding on the growth of maiden trees of sour cherry cv. 'Łutówka'. Acta Agrobot. 2006;59(2):215-221. http://dx.doi.org/10.5586/aa.2006.077

9. Baryła P, Kapłan M. The effect of the time and methods of budding on the quality of maiden tree and productivity of nursery of sour cherry cv. 'Łutówka'. Acta Agrobot. 2006;59(2):207-214. http://dx.doi. org/10.5586/aa.2006.076

10. Baryła P, Kapłan M. Estimation of the growth and the branching of cherry young trees of cultivar 'Łutówka' on six stocks. Ann Univ Mariae Curie-Skłodowska EEE. 2006;16:9-17.

11. Baryła P, Kapłan M. The effect of the time of budding of mahaleb cherry (Prunus mahaleb L.) seedlings on the quality of maiden trees of sour cherry (Prunus cerasus L.) 'Łutówka'. Acta Agrobot. 2012;65(4):163-168. http://dx.doi.org/10.5586/aa.2012.034

12. Baryła P, Kapłan M. The estimation of the growth and the branching of the six stocks under the cherry and sweet cherry trees. Acta Sci Pol Hortorum Cultus. 2005;4(1):119-129.

13. Grzyb ZS, Piotrowski W, Bielicki P, Sas-Paszt L, Malusa E. Effect of different fertilizers and amendments on the growth of apple and sour cherry rootstocks in an organic nursery. J Fruit Ornam Plant Res. 2012;20(1):43-53. http://dx.doi.org/10.2478/v10290-012-0004-x

14. Kramer S. Studies on growth characteristics in sour cherry both in the nursery and in the orchard. Archiv für Gartenbau. 1960;8:90-104.

15. Szpadzik E, Matulka M, Jadczuk-Tobjasz E. The growth, yielding and resistance to spring frost nine our cherry cultivars in central Poland. J Fruit Ornam Plant Res. 2009;17(2):139-148.

16. Lipecki J, Janisz A. The growth of different fruit species maiden trees in dependence on several environmental conditions. Ann Univ Mariae Curie-Skłodowska EEE. 2004;14:45-54.

17. Wociór S, Palonka S, Wójcik I. The effect of different methods of 
training on the growth of maiden trees of sour cherry cv. 'Eutówka' Zesz Probl Postępów Nauk Rol. 2009;539:753-758.

18. Baryła P. Relationship between the climatic factors and the growth of young cherry trees in a nursery. Acta Agrophys. 2005;6(1):31-41.

19. Lipecki J, Jacyna T, Lipa T, Szot I. The quality of apple nursery trees of knip-boom type as affected by the methods of propagation. Acta Sci Pol Hortorum Cultus. 2013;12(6):157-165.

20. Grzyb ZS, Piotrowski W, Sas-Paszt L, Bielicki P. The quality of sour cherry maidens fertilized with various biopreparations in an organic nursery. J Life Sci. 2013;7(4):400-409.

\section{Korelacje wzrostowe okulantów wiśni odmiany 'Kutówka'}

\section{Streszczenie}

Doświadczenia przeprowadzono w szkółce okulantów wiśni odmiany 'Łutówka' mnożonych na siewkach Prunus mahaleb L. w latach 1993, 2000-2003 i 2013 w rejonie Lublina. Mierzono wysokość drzewek, średnicę pnia oraz długość pędów bocznych. Wyniki różniły się między latami w zależności od przebiegu warunków meteorologicznych. Długość pędu bocznego zwiększała się w kierunku od wierzchołka drzewa ku jego dolnej części, przy czym wpływ położenia pędu na przewodniku na jego długość w większości przypadków był istotny. Nie stwierdzono różnic w długości pędów bocznych zależnie od liczby pędów na drzewie. Korelacja między średnicą pnia i sumą długości pędów bocznych była pozytywna i istotna. Korelacje między badanymi cechami charakteryzującymi wzrost okulantów wiśni były podobne do stwierdzanych w przypadku okulantów drzew typu „knip-boom” jabłoni. 